\title{
Public resale of mobile telephone minutes: An alternative access for low-income households in Colombia
}

\author{
Luis Fernando Gamboa, Luis H. Gutiérrez* \\ Department of Economics, Universidad del Rosario, Bogotá, Colombia
}

\section{A R T I C L E I N F O}

\section{Article history:}

Received 4 December 2008

Accepted 21 August 2009

\begin{abstract}
A B S T R A C T
In recent years in Colombia, the informal resale of mobile telephone minutes as an alternative means of access to mobile telephony has allowed access for many low-income people not financially eligible for mobile plans. With data from a 2007 survey of lowincome households in Colombia, we analyzed the main factors that determine the use of this kind of service. Using a probabilistic model (Logit), we found that people with a prepayment plan and those from smaller cities are more likely to use this alternative. Also, those subscribers in a plan with the leading carrier tend to use this service more often.
\end{abstract}

(c) 2010 Elsevier Ltd. All rights reserved.

\section{Introduction}

Mobile telephone use in Colombia exhibits interesting features compared to those in developed countries. One notable feature, seen in recent years, is an informal but very active resale market for mobile minutes, both in the streets and in microstores, fueled by demand for access to mobile telephony among low-income people. This has resulted in a distinction between mobile users (individuals who make calls using a mobile phone) and mobile subscribers (individuals who have a phone number assigned by their carrier).

In this paper we discuss the main socioeconomic features that make the informal resale of minutes attractive in Colombia. Using data from a survey ${ }^{1}$ of some 800 low-income people, our study provides new insights regarding the use of mobile telephony. Using a Logit model, we found that subscribers in prepayment plans and those with contracts with the leading carrier have a higher probability of using resale services. In addition, we found a positive relationship between income and the informal resale of minutes. To the best of our knowledge, this is the first study undertaken for a Latin American country that documents the factors determining the use of mobile telephony among low-income people.

\section{Related literature}

Two issues frequently appearing in the mobile telephony literature are patterns of diffusion and determinants of use. In terms of mobile telephony diffusion, several studies discuss mobile use [1-8]. However, they do not take into account financial factors, socioeconomic restrictions, or contract options as key variables that explain the rate of diffusion. However, it is widely accepted that prepaid plans are the most important factor in the diffusion and use of mobile phones worldwide.

A second focus of the literature is on the use of mobile technology [9-15]. Some of these studies look at the relatively low use and access at the bottom of the socioeconomic scale relative to use by high-income people. Owing to high initial prices,

\footnotetext{
* Corresponding author. Tel.: +57 $12970200 \times 676$.

E-mail address: lgutierr@urosario.edu.co (L.H. Gutiérrez).

1 Sponsored by the International Development Research Center (IDRC) of Canada.
} 
mobile telephony is typically oriented to people with a relatively high income, as most of the low- and middle-income population cannot afford it.

Consumers use different strategies to minimize their spending, and mobile telecommunication services is a good illustration. Among other strategies, one finds "beeping" and short message services (SMS). Beeping involves calling a number and hanging up before the mobile's owner answers, as a prearranged signal. It is widely recognized that SMS can be a convenient and lower-cost substitute for calls [16,17]. These are short-run strategies that people use daily [13].

Although it may seem surprising, demand for telecom services in most developing countries has been shown to be very high, especially among low-income earners [12,15]. Some authors estimate the proportion of mobile communications expenses to be about 10\% of their income [9-11]. More recently, Barrantes and Galperin [14] found that expenditures on mobile telephones by low-income individuals range between 5\% (Argentina) and 25\% (Mexico) of minimum wage in Latin American countries.

One of the main determinants of consumption among low-income people is the volatility of their income, which limits their ability to acquire products with a lower price per unit. As a consequence, mobile users employ different strategies to minimize their spending or to establish one-way communications at the lowest or no cost. Some examples are reported by Chakraborty [18] and Donner [17] for African countries, where beeping and "missed calls" with pre-established codes are common among the population. De Angoitia and Ramirez [19] showed that low-income people in Mexico prefer to have a mobile phone only for receiving calls and do not use SMS.

The use of such strategies to minimize mobile telephone expenses among low-income people goes beyond economic factors. In some cases, the use of mobile technologies is also dampened because of low levels of education in Latin American countries $[15,16]$.

\section{The mobile telephone market in Colombia}

Mobile telephony first appeared in Colombia in 1994. At the time, the country was divided into three different regions-Atlantic, Eastern, Western-and two companies provided services in each region: Celcaribe and Celumovil Costa in the Atlantic region, Comcel and Celumovil in the Eastern region, and Occel and Cocelco in the Western region.

The 1997 introduction of prepaid options increased the number of users since these new options allowed low- and middleincome people to subscribe (see Fig. 1.A). Then, in a series of acquisitions beginning in 2000 through 2003, Comcel gained control of Occel, and Celumovil gained control of Cocelco; America Movil from Mexico acquired Comcel, and BellSouth from the United States acquired Celumovil. These acquisitions led to a duopoly of Comcel and BellSouth and changed the industrial concentration in the mobile market.

This structure led to very high tariffs and limited use of mobile service by high-income people. At the end of 2003, a third operator entered the market, which generated strong market competition that led to price reductions, an increased number of users, and a reduction in the average revenue per user (ARPU) (see Fig. 1-B and 1-C). For a description of the evolution of Colombian mobile communications, see Gamboa and Otero [8].

\subsection{A new means of access}

In Colombia and other Latin American countries, a new way emerged for accessing mobile telecommunications. There is no precise information about when the phenomenon of buying mobile phone minutes in the streets and in small informal business places appeared. However, interviews with company executives suggest that it started in Colombia in 1999-some months after "unlimited use" postpaid plans began to appear. Two factors helped foster this activity: Colombia's economic situation and a new modality of mobile phone contracts in which customers could purchase an unlimited number of airtime minutes at a fixed rate.

In 1999 Colombia was in the midst of the deepest economic recession in a century. Unemployment was soaring, so people looked for new sources of income. It did not take long for them to realize they could sign up for mobile telephone plans that offered low prices per minute and then turn around and sell those minutes to other people. The more minutes they sell, the more revenue they realize, which reduced the cost of their postpaid plan. However, not everyone purchased postpaid plans because the phone companies demanded good credit and solid financial records from prospective customers. Thus lowincome people looked for ways to acquire the new unlimited airtime plans.

In its early stages, the resale of minutes was aimed at individuals who had no formal access to mobile telephone service. Since tariffs for mobile operators were high, reselling minutes became a lucrative alternative for people who already subscribed to a prepaid plan. Gutiérrez and Gamboa [15] provide detailed information about patterns of mobile telephone use among low-income people, which found that users with prepaid plans make fewer calls than those in postpaid contracts. Two factors might explain this pattern: the substantial price difference between prepaid and postpaid plans, and the "calling party pays" system. Today the resale of mobile services is growing rapidly in all major Colombian cities since resellers offer prices very close to the per-minute prices available in the best postpaid contract plans. Mobile users realized they can save money by using informal resale rather than having a prepaid plan. For those reselling mobile telephone minutes, such sales are often their only source of income.

There are at least two different types of vendors. Many informal vendors are located in crowded sites in the major Colombian cities, i.e., near bus stops, shopping malls, universities, and so on. Each vendor has at least one mobile device 

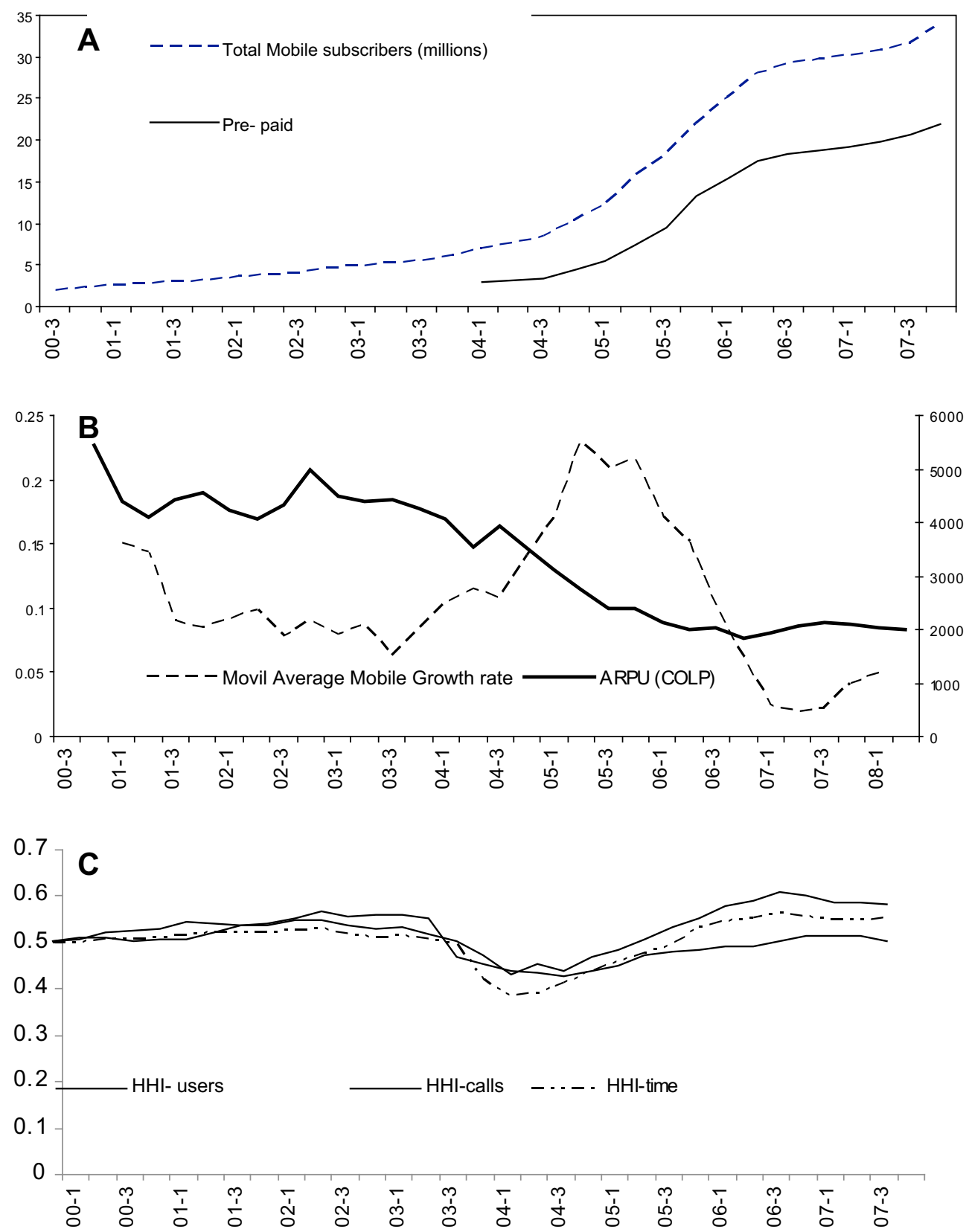

Fig. 1. A. Mobile subscribers in Colombia. B. Mobile indicators. ARPU: Average revenue per user. C. Mobile market concentration. HHI: Herfindahl-Hirshman Index. Source: Ministry of communications.

that allows customers to make in-network calls, which are cheaper than out-of-network calls. It is also possible to find informal vendors reselling minutes in small neighborhood tiendas (grocery stores) in the low- and middle-income neighborhoods.

Due to price differentials between in-network and out-of-network calls, and between prepaid and postpaid plans, the second type of vendors are formal cybercafes, which offer access to the Internet, and to local and long-distance calls. In contrast to vendors on the street, these vendors have formally organized communications on the premises and legal contracts with the mobile companies.

However, the bulk of the business is informal, conducted by individuals waving a makeshift sign saying llamadas (calls). These informal vendors move easily from one place to another looking for better demand. In many popular stops, a dozen or more individual sellers can be found; in less busy sites, informal street vendors often sell cigarettes, candy, and other treats in addition offering the resale of mobile phone services. 
The intersection of these various facets of the Colombian mobile telephone market allowed the whole telecommunication sector to grow at a higher rate, and led to changes in its composition. In the mid-1990s, the main telecommunication subsector was fixed telephony; now mobile telephony is the leading sub-sector. Between 2004 and 2007, the number of mobile users grew by $227 \%$, while the mobile sector increased its income share $11 \%$ in 1996 to $41 \%$ in 2007. By the end of 2007 there were approximately 34 million mobile phone subscribers and about 8 million fixed-line telephone subscribers. As indicated by Gamboa [20], this growth is attributable primarily to the increase in consumption by low-income people who are now able to access mobile phone service via prepayment (about 84\%).

\section{Data}

In May 2007, the IDRC and DIRSI (Dialogo Regional sobre la Sociedad de la Información) sponsored a telecommunications survey that focused on low-income households in several Latin American and Caribbean countries. In Colombia, 800 low-income people were surveyed in the cities of Bogotá, Medellín, Pasto, and Villavicencio. The survey questions gathered information about access to mobile and fixed telephones; consumption and use patterns; and socioeconomic information such as gender, income, and housing conditions. The survey also included questions about the purchase of informal resale minutes. Gutiérrez and Gamboa [15] provide a detailed description of the Colombian study; Table 1 defines the variables.

Among the most significant findings, 713 respondents (89\%) used mobile telephones, but only 61\% (492 people) owned a mobile phone. People who used prepaid plans preferred to use their phones to receive calls rather than to make calls. Only $37 \%$ of respondents owned both mobile and fixed phones, while about $13 \%$ of respondents had neither. This implies that about $50 \%$ of low-income Colombians have only one means of communication-either a fixed or a mobile phone. This high percentage can be explained by collateral constraints such as access to credit and income instability. Also, most Colombians live in leased housing, and it is common for landlords to refuse to allow tenants to contract for fixed-line telephone service because of the risk that the landlord will be responsible for unpaid bills left by tenants.

Table 2 shows that the average monthly income of those surveyed was around US\$100, and most did not have complete secondary education. As Gutiérrez and Gamboa [15] show, postpaid contract users call more frequently than prepaid contract users. On average, from 2003 to 2004 most mobile users in the survey were newcomers, i.e., they had lived in the cities for less than three years.

Table 2 also shows that about three-quarters of the people who own a mobile phone used informal resale of minutes and most of them had prepayment plans. In estimating their level of use, we determined that the number of users who used informal resale of minutes but did not have a phone was 183 in the survey (22.9\%). The number of users who owned a phone was 372 (76.4\% of phone owners).

The survey asked about four cost-minimizing strategies that mobile users might use: (1) beeping, (2) using the phone only to receive calls, (3) sending SMS, and (4) buying informally resold mobile minutes (see Table 3). The use of informal resale minutes was by far the most frequent strategy used to minimize expenditure; SMS was the least used. Women were more prone to use the phone only for receiving calls. Beeping was more common among young people, and it was found to be positively related to wealth. People who used prepayment plans preferred to use their mobile phone to receive calls, instead using informal resale minutes when they needed to make a call. Finally, we found that those who used the mobile carrier that had the lowest market share utilized informal resale most, which can be explained by the price difference between less expensive in-network calls and more expensive out-of-network calls.

Table 1

Definitions of variables. Source: [15].

\begin{tabular}{|c|c|}
\hline Name & Description \\
\hline Gender & Dummy variable equal to 1 if the person is men, 0 elsewhere \\
\hline Age & Age of the person (continuous variable) \\
\hline Age 2 & Age squared \\
\hline Log(income) & Per capita income (in logarithms) \\
\hline SES & Socioeconomic index (ranges from 0 to 100 ) \\
\hline Schooling & Educative level (none, primary, secondary, higher) \\
\hline Medellin & Dummy variable equal to one if the person lives in Medellin \\
\hline Small city dummy & Dummy variable equal to one if the person lives in Pasto or Villavicencio \\
\hline Labor status & Dummy variable equal to one if the person is employed and cero if he/she is unemployed or inactive \\
\hline Size of household & Number of people in household \\
\hline Owns a fixed phone & Dummy variable equal to 1 if the person has a fixed line in household \\
\hline Sensibility to price & $\begin{array}{l}\text { This is a dummy variable constructed from a question done to people about their probability of change the use when price } \\
\text { change (up and down). It is equal to } 1 \text { if the person change her level of use when price change }\end{array}$ \\
\hline Type of contract & Dummy variable equal to 1 if he/she does not have a mobile or have it in the modality of prepayment \\
\hline Owner & Dummy variable equal to 1 if he/she owns a mobile phone \\
\hline Firm leader & Dummy variable equal to 1 if he/she has a mobile phone from the higher mobile operator \\
\hline Use of Internet & Number of days in which he/she used Internet during the last month \\
\hline ICT index & Internet + fixed. Then it takes values from 0 to 2 . \\
\hline
\end{tabular}


Table 2

Summary statistics. Source: DIRSI survey.

\begin{tabular}{|c|c|c|c|c|c|}
\hline & $\mathrm{N}$ & Mean & Std Dev. & Min & Max \\
\hline Age & 492 & 36.5 & 12.23 & 15 & 70 \\
\hline Per capita income (US dollar) & 492 & 116.3 & 101.26 & 0 & 782.89 \\
\hline Years of education & 492 & 8.5 & 3.803 & 0 & 17 \\
\hline Overcrowding & 492 & 1.9 & 0.935 & 0.5 & 6 \\
\hline Female & 315 & $64.0 \%$ & & & \\
\hline Fixed & 301 & $61.2 \%$ & & & \\
\hline \multicolumn{6}{|l|}{ Mobile } \\
\hline Prepaid & 439 & $89.2 \%$ & & & \\
\hline No calls made (weekly) & 380 & 12.6 & 13.9 & 1 & 100 \\
\hline No. calls received (weekly) & 417 & 13 & 14.3 & 1 & 50 \\
\hline SMS sent (weekly) & 114 & 7.9 & 10.1 & 1 & 60 \\
\hline Daily spending & 387 & 0.2 & 0.2 & 0.01 & 1.49 \\
\hline Years of use & 439 & 3.2 & 2.2 & 0 & 11 \\
\hline Postpaid & 53 & $10.8 \%$ & & & \\
\hline No calls made (weekly) & 52 & 33.5 & 35.6 & 2 & 100 \\
\hline No. calls received (weekly) & 53 & 29.7 & 33.7 & 2 & 100 \\
\hline SMS sent (weekly) & 23 & 11.2 & 10.5 & 2 & 50 \\
\hline Daily spending & 52 & 1.5 & 0.8 & 0.35 & 4.38 \\
\hline Years of use & 53 & 3.8 & 2.5 & 0 & 11 \\
\hline Informal users & 376 & $76.4 \%$ & & & \\
\hline No calls made & 339 & 14.0 & 16.6 & 1 & 100 \\
\hline No. calls received & 363 & 15.98 & 18.6 & 1 & 180 \\
\hline
\end{tabular}

Calculations by the authors

Table 3

Strategies used to reduce costs among mobile owners. Source: DIRSI survey.

\begin{tabular}{|c|c|c|c|c|c|}
\hline & $N$ & Beeping & Phone-receiver & SMS & Informal resale \\
\hline \multicolumn{6}{|l|}{ Gender } \\
\hline Male & 177 & 40.7 & 48.0 & 9.6 & 77.4 \\
\hline Female & 315 & 45.1 & 61.6 & 8.6 & 75.8 \\
\hline \multicolumn{6}{|l|}{ Age } \\
\hline $12-18$ years & 51 & 49.0 & 62.7 & 15.7 & 80.4 \\
\hline $19-30$ years & 182 & 55.5 & 58.2 & 12.1 & 78.0 \\
\hline $31-50$ years & 200 & 33.6 & 52.5 & 22.7 & 73.0 \\
\hline$>50$ years & 59 & 27.1 & 61.0 & 6.8 & 79.6 \\
\hline \multicolumn{6}{|l|}{ City } \\
\hline Bogotá & 127 & 52.7 & 71.6 & 14.9 & 80.3 \\
\hline Medellín & 100 & 43 & 58 & 16 & 65 \\
\hline Villavicencio & 149 & 44.3 & 44.9 & 3.4 & 69.1 \\
\hline Pasto & 116 & 32.7 & 54.3 & 3.5 & 91.4 \\
\hline \multicolumn{6}{|c|}{ Quintile of SES } \\
\hline 1 & 78 & 37.2 & 66.7 & 11.5 & 78.2 \\
\hline 2 & 96 & 42.7 & 67.7 & 10.4 & 69.8 \\
\hline 3 & 97 & 41.2 & 55.7 & 11.3 & 74.2 \\
\hline 4 & 104 & 45.2 & 57.7 & 9.6 & 83.6 \\
\hline 5 & 117 & 48.7 & 41.0 & 3.4 & 76.1 \\
\hline \multicolumn{6}{|c|}{ Education level } \\
\hline Basic or less & 280 & 37.1 & 63.2 & 10 & 77.8 \\
\hline Secondary & 146 & 50 & 52.1 & 8.9 & 71.1 \\
\hline Superior & 66 & 56.0 & 39.4 & 6.8 & 81.8 \\
\hline \multicolumn{6}{|c|}{ Type of contract } \\
\hline Post-paid & 53 & 49.0 & 30.2 & 7.5 & 49.1 \\
\hline Pre-paid & 439 & 42.8 & 59.9 & 9.1 & 79.7 \\
\hline \multicolumn{6}{|l|}{ Firm size } \\
\hline Largest & 348 & 44.2 & 58.3 & 8.6 & 77.6 \\
\hline Medium & 130 & 40 & 52.3 & 8.4 & 71.5 \\
\hline Small $^{\mathrm{a}}$ & 14 & & & & 92.9 \\
\hline Total & 492 & 43.5 & 56.7 & 8.9 & 76.4 \\
\hline
\end{tabular}

Calculations by the authors.

a Due to little data, percentages are not shown. 


\section{Methodology and results}

Following the design of the survey, we divide our estimation into two parts. In the first part, we included only users who own a mobile phone (492) because most of the questions about usage habits were directed only to them. The results for the first portion are shown in Table 4. In the second estimation, we include all users (713) without regard to whether they subscribed to any mobile telephone plan (see results in Table 4). In this part, information regarding patterns of use and use of other cost-reducing strategies was not available from those who did not have a mobile phone or subscription plan.

In both approaches, we included one variable to capture how being more familiar with digital technology affected the use of informal telephony. As a proxy for the level of awareness regarding information and communication technology (ICT) use, we constructed an ICT index [20]. And since respondents tended to under-report income, we constructed a proxy for standard of living, which we called the socioeconomic index (SES). It was constructed by applying principal components to several variables (e.g., house materials, economic dependence, head of household's education level, overcrowding, proportion of children in school, and schooling of people above 12 years old). Five different specifications labeled (1)-(5) are presented for the two econometric exercises. Each of them uses alternative variables.

Since our dependent variable is discrete, a probabilistic model was used. In the first estimation, the dependent variable is defined as whether or not an individual who owned a mobile phone made calls using mobile telephone minutes purchased from the street. The explanatory variables include, among others: type of contract (prepaid or postpaid); gender; age; socioeconomic status proxied by income, size of household and degree of overcrowding, and labor status; other costreduction strategies used; use of fixed-line telephone(s); and a dummy that takes the value of 1 when the respondent's mobile operator was the leading carrier in the market.

Our results found that people in prepayment plans had a higher probability of using resold mobile telephone minutes. This could be because prepaid and postpaid calls differ in price, or it could also be explained by the distance people had to travel to buy a new prepaid card. A second interesting finding is the significance of the variable firm leader, which tells us that the dominant firm's subscribers tend to use informal resale more. This revealed that the lead operator has high interconnection

Table 4

Dependent variable: use of informal mobile minutes by OWNERS. Marginal effects.

\begin{tabular}{|c|c|c|c|c|c|}
\hline & (1) & (2) & (3) & $(4)$ & (5) \\
\hline Gender & $\begin{array}{l}0.020 \\
(0.06)\end{array}$ & $\begin{array}{l}0.0295 \\
(0.068)\end{array}$ & $\begin{array}{l}0.0321 \\
(0.064)\end{array}$ & $\begin{array}{l}0.0323 \\
(0.064)\end{array}$ & $\begin{array}{l}0.0295 \\
(0.068)\end{array}$ \\
\hline Age & $\begin{array}{l}0.0230 \\
(0.013)\end{array}$ & $\begin{array}{l}0.0347^{* * *} \\
(0.014)\end{array}$ & $\begin{array}{l}0.0351^{* * *} \\
(0.014)\end{array}$ & $\begin{array}{l}0.0352^{* * *} \\
(0.014)\end{array}$ & $\begin{array}{l}0.0346^{* * *} \\
(0.014)\end{array}$ \\
\hline $\mathrm{Age}^{2}$ & $\begin{array}{l}-0.0003^{* *} \\
(0.000)\end{array}$ & $\begin{array}{l}-0.0004^{* * *} \\
(0.0002)\end{array}$ & $\begin{array}{l}-0.0004^{* * *} \\
(0.0002)\end{array}$ & $\begin{array}{l}-0.0004^{* * *} \\
(0.0002)\end{array}$ & $\begin{array}{l}-0.0004^{* * * *} \\
(0.0002)\end{array}$ \\
\hline Log(income) & & $\begin{array}{l}0.0653^{* * *} \\
(0.033)\end{array}$ & $\begin{array}{l}0.0660^{* * * *} \\
(0.033)\end{array}$ & $\begin{array}{l}0.0672^{* * *} \\
(0.032)\end{array}$ & $\begin{array}{l}0.0653^{* * *} \\
(0.033)\end{array}$ \\
\hline SES & $\begin{array}{l}0.010^{* * *} \\
(0.005)\end{array}$ & & & & \\
\hline Type of contract & $\begin{array}{l}0.670^{* * *} \\
(0.034)\end{array}$ & $\begin{array}{l}0.6796 * * * \\
(0.0351)\end{array}$ & $\begin{array}{l}0.6797^{* * *} \\
(0.0351)\end{array}$ & $\begin{array}{l}0.6786^{* * *} \\
(0.0354)\end{array}$ & $\begin{array}{l}0.6796 * * * \\
(0.0351)\end{array}$ \\
\hline Schooling & $\begin{array}{l}-0.000 \\
(0.000)\end{array}$ & $\begin{array}{l}0.000 \\
(0.0006)\end{array}$ & $\begin{array}{l}0.000 \\
(0.0006)\end{array}$ & $\begin{array}{l}0.000 \\
(0.0005)\end{array}$ & $\begin{array}{l}0.000 \\
(0.0006)\end{array}$ \\
\hline Small city dummy & $\begin{array}{l}0.077 \\
(0.065)\end{array}$ & $\begin{array}{l}0.0829 \\
(0.066)\end{array}$ & $\begin{array}{l}0.0830 \\
(0.066)\end{array}$ & $\begin{array}{l}0.0747 \\
(0.065)\end{array}$ & $\begin{array}{l}0.0829 \\
(0.066)\end{array}$ \\
\hline Medellin & $\begin{array}{l}-0.173^{* * *} \\
(0.073)\end{array}$ & $\begin{array}{l}-0.1602^{* * *} \\
(0.079)\end{array}$ & $\begin{array}{l}-0.1603^{* * *} \\
(0.079)\end{array}$ & $\begin{array}{l}-0.1530^{* * *} \\
(0.077)\end{array}$ & $\begin{array}{l}-0.1602^{* * *} \\
(0.079)\end{array}$ \\
\hline Labor status & $\begin{array}{l}0.060 \\
(0.598)\end{array}$ & $\begin{array}{l}0.0098 \\
(0.062)\end{array}$ & & & $\begin{array}{l}0.0098 \\
(0.062)\end{array}$ \\
\hline Firm leader & $\begin{array}{l}0.2375^{* * *} \\
(0.055)\end{array}$ & $\begin{array}{l}0.2295^{* * *} \\
(0.059)\end{array}$ & $\begin{array}{l}0.2300^{* * *} \\
(0.059)\end{array}$ & $\begin{array}{l}0.2298^{* * *} \\
(0.0590\end{array}$ & $\begin{array}{l}0.2295^{* * *} \\
(0.059)\end{array}$ \\
\hline Internet user & $\begin{array}{l}0.1302^{*} \\
(0.072)\end{array}$ & $\begin{array}{l}0.1151^{*} \\
(0.076)\end{array}$ & $\begin{array}{l}0.1135^{*} \\
(0.075)\end{array}$ & $\begin{array}{l}0.1139 \\
(0.074)\end{array}$ & $\begin{array}{l}0.0838 \\
(0.096)\end{array}$ \\
\hline Size of household & & & & $\begin{array}{l}0.0014 \\
(0.017)\end{array}$ & \\
\hline Owns a fixed phone & $\begin{array}{l}0.0137 \\
(0.059)\end{array}$ & $\begin{array}{l}0.0320 \\
(0.062)\end{array}$ & $\begin{array}{l}0.0320 \\
(0.062)\end{array}$ & & \\
\hline Sensibility to price & $\begin{array}{l}-0.0237 \\
(0.062)\end{array}$ & $\begin{array}{l}-0.0286 \\
(0.066)\end{array}$ & $\begin{array}{l}-0.0287 \\
(0.066)\end{array}$ & $\begin{array}{l}-0.0272 \\
(0.066)\end{array}$ & $\begin{array}{l}-0.0286 \\
(0.066)\end{array}$ \\
\hline ICT index & & & & & $\begin{array}{l}0.0320 \\
(0.061)\end{array}$ \\
\hline Hosmer-Lemeshow $\mathrm{Chi}^{2}(8)$ & 30.24 & 22.76 & 22.22 & 18.92 & 22.76 \\
\hline Prob $<\mathrm{Chi}^{2}$ & 0.002 & 0.003 & 0.004 & 0.015 & 0.003 \\
\hline Pseudo- $R$ & 0.427 & 0.43 & 0.44 & 0.43 & 0.43 \\
\hline $\log$ & -282.38 & -259.84 & -260.0 & -260 & -259 \\
\hline
\end{tabular}

Standard errors in parentheses. ${ }^{* * *} p<001$. 
Table 5

Dependent variable: use of informal mobile minutes by USERS. Marginal effects.

\begin{tabular}{|c|c|c|c|c|c|c|}
\hline Variable & $(1)$ & $(2)$ & (3) & (4) & (5) & (6) \\
\hline Gender & $\begin{array}{l}0.000 \\
(0.035)\end{array}$ & $\begin{array}{l}0.007 \\
(0.033)\end{array}$ & $\begin{array}{l}0.003 \\
(0.035)\end{array}$ & $\begin{array}{l}0.008 \\
(0.035)\end{array}$ & $\begin{array}{l}-0.003 \\
(0.034)\end{array}$ & $\begin{array}{l}0.001 \\
(0.035)\end{array}$ \\
\hline Age & $\begin{array}{l}0.002 \\
(0.002)\end{array}$ & $\begin{array}{l}0.001 \\
(0.001)\end{array}$ & $\begin{array}{l}0.002 \\
(0.001)\end{array}$ & $\begin{array}{l}0.001 \\
(0.001)\end{array}$ & $\begin{array}{l}0.002 \\
(0.001)\end{array}$ & $\begin{array}{l}0.002 \\
(0.001)\end{array}$ \\
\hline Log(income) & $\begin{array}{l}0.018 \\
(0.017)\end{array}$ & & $\begin{array}{l}0.021 \\
(0.017)\end{array}$ & & $\begin{array}{l}0.017 \\
(0.017)\end{array}$ & $\begin{array}{l}0.018 \\
(0.017)\end{array}$ \\
\hline SES & & $\begin{array}{l}0.001^{* * *} \\
(0.002)\end{array}$ & & & & \\
\hline Type of contract & $\begin{array}{l}0.377^{* * *} \\
(0.077)\end{array}$ & $\begin{array}{l}0.373^{* * *} \\
(0.075)\end{array}$ & $\begin{array}{l}0.368^{* * *} \\
(0.077)\end{array}$ & $\begin{array}{l}0.359^{* * *} \\
(0.078)\end{array}$ & $\begin{array}{l}0.386^{* * *} \\
(0.076)\end{array}$ & $\begin{array}{l}0.382^{* * *} \\
(0.076)\end{array}$ \\
\hline Small city dummy & $\begin{array}{l}0.131^{* * *} \\
(0.032)\end{array}$ & $\begin{array}{l}0.150^{* * *} \\
(0.033)\end{array}$ & $\begin{array}{l}0.126^{* * *} \\
(0.032)\end{array}$ & $\begin{array}{l}0.133^{* * *} \\
(0.032)\end{array}$ & $\begin{array}{l}0.143^{* * *} \\
(0.034)\end{array}$ & $\begin{array}{l}0.143^{* * *} \\
(0.034)\end{array}$ \\
\hline Labor status & $\begin{array}{l}-0.013 \\
(0.034)\end{array}$ & & $\begin{array}{l}-0.020 \\
(0.033)\end{array}$ & $\begin{array}{l}0.011 \\
(0.033)\end{array}$ & & $\begin{array}{l}-0.015 \\
(0.033)\end{array}$ \\
\hline Size of household & $\begin{array}{l}0.002 \\
(0.009)\end{array}$ & $\begin{array}{l}0.002 \\
(0.009)\end{array}$ & $\begin{array}{l}0.001 \\
(0.009)\end{array}$ & $\begin{array}{l}0.000 \\
(0.009)\end{array}$ & $\begin{array}{l}0.002 \\
(0.009)\end{array}$ & $\begin{array}{l}0.001 \\
(0.009)\end{array}$ \\
\hline Owner & $\begin{array}{r}-0.020 \\
(0.034)\end{array}$ & $\begin{array}{l}-0.0342 \\
(0.033)\end{array}$ & $\begin{array}{l}-0.019 \\
(0.034)\end{array}$ & $\begin{array}{c}-0.034 \\
(0.033)\end{array}$ & $\begin{array}{r}-0.022 \\
(0.034)\end{array}$ & $\begin{array}{l}-0.020 \\
(0.034)\end{array}$ \\
\hline Internet user & $\begin{array}{l}0.056 \\
(0.036)\end{array}$ & & & & & \\
\hline ICT index & & $\begin{array}{l}0.037 \\
(0.026)\end{array}$ & & & $\begin{array}{l}0.039^{* *} \\
(0.025)\end{array}$ & $\begin{array}{l}0.038^{* *} \\
(0.025)\end{array}$ \\
\hline Log Likelihood & -316.6 & -347.7 & -318.0 & -349.4 & -317.1 & -316.0 \\
\hline Holmer-Lemeshow & 13.77 & 12.04 & 10.06 & 9.33 & 8.37 & 10.88 \\
\hline Prob $>\mathrm{Chi}^{2}$ & 0.0881 & 0.149 & 0.2205 & 0.315 & 0.39 & 0.2 \\
\hline
\end{tabular}

Standard errors in parentheses. ${ }^{* * *} p<001$.

rates aimed at increasing its competitors' costs. During 2006 and 2007, prices for out-of-net calls from the leading carrier were higher than those of the other two operators.

We also found a positive relationship between income (or its proxy the socioeconomic index (SES)), and the use of informal resale of minutes. This finding may have emerged from the fact that among the low-income people surveyed, those with relatively higher income tended to be more frequent mobile users. A variable capturing users' sensibility to price changes was also included, but it was not as important as the ICT index in explaining the use of resold mobile telephone minutes.

In the second estimation (see Table 5), the dependent variable is whether or not an individual who owns a mobile phone also makes use of informal resale of mobile telephone minutes. It is important to note that in this estimation, the number of available observations increases and some explanatory variables were dropped and others added. For example, we included a variable called Internet user, which is a dummy variable with value of 1 if the respondent was an Internet user and zero otherwise. For estimation purposes, we use the ICT Index and Internet user variable both separately and jointly.

In this case, our findings are shown in Table 5. We tested several specifications, and the results were robust to them. The variable type of contract showed that people using a postpaid plan were less likely to use informal resale of minutes. It is interesting to note, however, that Internet use had a positive impact on the use of informal resale of mobile phone minutes on the streets. One explanation is that people who are familiar with ICT want or need to be in more contact with their network of relatives and friends. We also found that people from small cities (e.g., Pasto and Villavicencio) used the informal market for reselling mobile minutes to communicate more often than did people from the capital city of Bogotá. This corroborates a finding in Gutiérrez and Gamboa [21] that people in Bogotá and México City are, on average, more adapted to digital communications. This is not surprising since people living in capital cities have more access to ICT (fixed, public, or mobile telephony).

The variable owner aims to identify whether people with a mobile device tend to use the informal resale of minutes with a higher probability than those who do not have a mobile device. Although it is not significant, the estimated coefficient has the expected sign.

Finally, we found that there are no gender differences in the use of this alternative form of communication.

\section{Conclusion}

Our analysis showed that there are different motivations for using the informal resale of mobile minutes on the streets in Colombia. In general, people who have prepayment plans with the leading carrier are more likely to use this alternative access to communication. We also found that level of income affects the use of these informal services. Poor people who have more familiarity with digital technologies tend to use this type of connection more, although the effect is not significant.

During the last year, competition among mobile telephone service providers in Colombia has increased which could result in lower prices. If price differences among providers' plans converge, will this reduce the incentive to use the informal resale of minutes? If so, policymakers and regulators should focus on the credit barriers that restrict access to mobile telephone use by poor people. Also, from the supply side, the informal resale of mobile phone minutes is an alternative source of income for 
people who have little education and few job opportunities. Further research could study the supply side of informal resale and the characteristics of vendors.

\section{Acknowledgments}

We would like to thank to Luis Eduardo Fajardo, Jesus Otero, and Patricia Mason for their comments and suggestions on a previous version. We also thank the IDRC, DIRSI, and Universidad del Rosario for financial support. The usual disclaimer applies.

\section{References}

[1] Gruber H. Competition and innovation: the diffusion of mobile telecommunications in Central and Eastern Europe. Information Economics and Policy 2001;13(1):19-34.

[2] Gruber H, Verboven F. The diffusion of mobile telecommunications services in the European Union. European Economic Review 2001;45(3):577-88.

[3] Botehlo A, Costa L. The diffusion of cellular phones in Portugal. Telecommunications Policy 2004;28(5):427-37.

[4] Massini S. The diffusion of mobile telephony in Italy and the UK: an empirical investigation. Economics of Innovation \& New Technology 2004;13(3): $251-77$.

[5] Hodge J. Tariff structures and access substitution of mobile cellular for fixed line in South Africa. Telecommunications Policy 2005;29(7):493-505.

[6] Carvalho A. Diffusion of mobile phones in Portugal: unexpected success? Paper presented at Innovation Pressure International ProAct Conference, Finland; 2006.

[7] Michalakelis C, Varuotas D, Sphicopoulos T. Diffusion models of mobile telephony in Greece. Telecommunications Policy 2008;32(3):234-45.

[8] Gamboa L, Otero J. An estimation of the pattern of diffusion of mobile phones: the case of Colombia. Telecommunications Policy 2008;33(10-11): 611-20.

[9] Intelecon website Results from the largest demand survey in Nigeria. Available from:, <http://www.inteleconresearch.com/pages/news.html>; July 2005 .

[10] Gillwald A, editor. Toward an African e-index: household and individual ICT access and usage across 10 African countries. Research ICT Africa; 2005.

[11] Scott D, Garforth SC, Mascarenhas JR, and McKemey K. The economic impact of telecommunications on rural livelihoods and poverty reduction: a study of rural communities in India (Gujarat), Mozambique, and Tanzania (CTO for UK Department for International Development, 2005).

[12] GSM Latin America. Social impact of mobile telephony in Latin America. Frost \& Sullivan; 2006.

[13] Zainudeen A, Samarajiva R, Abeysuriya A. Telecom use on a shoestring: strategic use of telecom services by the financially constrained in South Asia. WDR Dialogue Theme, 3rd cycle, Discussion Paper WDR 0604; 2006.

[14] Barrantes R, Galperin H. Can the poor afford mobile telephony? Evidence from Latin America. Telecommunications Policy 2008;32(8):521-30.

[15] Gutiérrez LH, Gamboa LF. Oportunidades móviles. Pobreza y acceso a la telefonía en América Latina y el Caribe: el caso de Colombia. Available from, <http://www.dirsi.net>; 2007.

[16] Galperín H, Molinari A. Oportunidades Móviles. Pobreza y acceso a la telefonía en América Latina y el Caribe: el caso de Argentina. Available at, $<$ http://www.dirsi.net>; 2007.

[17] Donner J. The rules of beeping: exchanging messages via intentional "missed calls" on mobile phones. Journal of Computer-Mediated Communication 2008; $13: 1-22$.

[18] Chakraborty D. The case of mobile phones in Sitakund. Available from: <http://www.i4donline.net/issue/may04/sitakund_full.htm>; 2004.

[19] De Angoitia R, Ramirez F. Estrategias utilizadas para minimizar costos por los usuarios de telefonía celular de sectores de bajos ingresos de México. Available from, <http://www.dirsi.net $>$; 2007.

[20] Gamboa LF. Patrones de acceso y análisis de gasto en Telefonía Móvil Celular en Colombia 2001-2006. DIRSI. Available from, <http://www.dirsi.net/ files/investigaciones_breves/gamboa.pdf >; 2007.

[21] Digital divide among low-income people in Colombia, Mexico and Peru. Forthcoming The Information Society 2010.

Luis Fernando Gamboa is assistant professor of Economics at the Universidad del Rosario, Bogotá, Colombia. He received his MSc. in industrial organization from Universidad Carlos III de Madrid in Spain. He is currently a PhD student. His research interests are in the areas of applied economics, applied econometrics, and industrial economics.

Luis H. Gutiérrez is professor of Economics at the Universidad del Rosario, Bogotá, Colombia. He has a PhD from the University of Florida. He teaches microeconomics, financial economics, and industrial organization. His current research activities are mobile telecommunications, regulatory governance, and corporate governance. 